\title{
頭蓋内電極を用いた嚥下関連脳活動の解析と解読
}

\author{
橋本 洋章 ${ }^{1,2,3)}$. 亀田成 司 ${ }^{1)}$ - 前 澤 仁 志 ${ }^{1)} \cdot$ 押 野 悟 ${ }^{4}$ \\ 谷直 樹 ${ }^{4)}$ ・クー・ウイミン ${ }^{4)}$ ・柳 澤 琢 史 ${ }^{4)}$

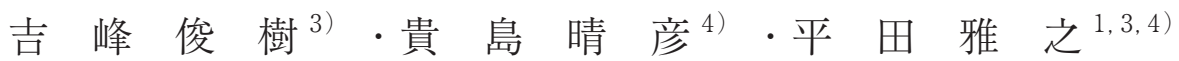

\section{The Analysis and Decoding of Swallowing-related Neural Activities Using Intracranial Electrodes}

\author{
Hiroaki Hashimoto ${ }^{1,2,3)}$, Seiji Kameda ${ }^{1)}$, Hitoshi Maezawa ${ }^{1)}$, Satoru Oshino ${ }^{4)}$ \\ Naoki Tani ${ }^{4}$, Hui Ming Khoo"), Takufumi Yanagisawa ${ }^{4)}$ \\ Toshiki Yoshimine ${ }^{3)}$, Haruhiko Kishima ${ }^{4)}$ and Masayuki Hirata ${ }^{1,3,4)}$
}

\begin{abstract}
The present study clarified the swallowing-related neural activities using human intracranial electrodes. Eight epileptic participants fitted with intracranial electrodes on the orofacial cortex were asked to swallow a water bolus, and cortical oscillatory changes were investigated. High $\gamma(75-150 \mathrm{~Hz})$ power increases associated with swallowing were observed in the subcentral area. To decode swallowing intention, ECoG signals were converted into images whose vertical axes were the electrode's contacts and whose horizontal axis was the time in milliseconds; these findings were used as training data. Deep transfer learning was carried out using AlexNet, and the power in the high- $\gamma$ band was used to create the training image set. The accuracy reached $74 \%$, and the sensitivity reached $83 \%$. We showed that a version of AlexNet pre-trained with visually meaningful images can be used for transfer learning of visually meaningless images made up of ECoG signals This study demonstrated that swallowing-related high $\gamma$ activities were observed in the subcentral area, and deep transfer learning using high $\gamma$ activities enabled us to decode the swallowing-related neural activities.
\end{abstract}

Keywords : swallowing-related neural activity, high $\gamma$ band, deep transfer learning, intracranial electrodes

は じめ に

我々の研究室では，病気や加齢などで失われた燕下機能 をBrain Machine Interface（BMI）の技術を用いて再建す ることを構想し，2014 年から研究を継続している．BMI とは1）脳活動を計測し，2）その意味を機械学習などの技 術により解読し， 3）外部機器へと出力する, ヒトと外部 環境をつなげる技術の総称である。

嚥下BMIの実現のためには，まず1）嚥下時脳活動の計 測と解析，が必要である。曣下に関連して大脳が活動する ことはfunctional magnetic resonance imaging (fMRI) ${ }^{1)}$, positron emission tomography $(\mathrm{PET})^{2)}$, magnetoencephalography $(\mathrm{MEG})^{3)}$ などの非侵襲的な脳活動計測法により
明らかにされている。また，2）嚥下時脳活動の解読につ いても頭皮脳波を用いた解読 ${ }^{4)}$ が報告されている。これら の結果は主に非侵襲的な方法で計測された脳活動を使用し ているが，そのような信号にはノイズ混入の問題があり， また時空間分解能が高い脳信号とは言い難い.

そこで我々は頭蓋内電極により計測される $\mathrm{S} / \mathrm{N}$ 比の高い 脳信号を用いて燕下関連脳活動の解析と解読を計画した。 頭蓋内電極を用いた嚥下関連脳活動の報告 ${ }^{5)}$ はあるもの の, 嚥下とHigh $\gamma$ 帯域 $(>50 \mathrm{~Hz})$ と呼ばれる高周波脳律 動との関係は明らかではなかった。高周波脳律動は頭蓋内 電極により計測可能であり, 高周波脳律動を用いれば脳活 動の解読精度を向上させることが可能であると報告されて いる ${ }^{6.7)}$. またHigh $\gamma$ 活動は低周波帯域活動に比べより脳

1) 大阪大学大学院医学系研究科脳機能診断再建学共同研究講座

2) 国家公務員共済組合連合会大手前病院脳神経外科

3）大阪大学国際医工情報センター臨床神経医工学

4) 大阪大学大学院医学系研究科脳神経外科

1) Department of Neurological Diagnosis and Restoration, Graduate School of Medicine, Osaka University

2) Department of Neurosurgery, Otemae Hospital

3) Endowed Research Department of Clinical Neuroengineering, Global Center for Medical Engineering and Informatics, Osaka University

4) Department of Neurosurgery, Graduate School of Medicine, Osaka University 
機能局在を反映していると考えられており ${ }^{8)}$, 体性感覚 ${ }^{9)}$, 運動 ${ }^{8)}$, 言語 ${ }^{10)}$, ワーキングメモリー ${ }^{11)}$ などに関与して いることから，嚥下にもHigh $\gamma$ 活動が関与していること が予想された。

頭蓋内電極が留置されたてんかん患者を対象とし, 水の 嚥下課題を行い, その際の頭蓋内脳波の計測を計画したが, 研究当初は頭蓋内脳波計測と同時に行える嚥下モニタリン グ法が存在しなかった。そこでモーションキャプチャー装 置である Kinect v2 (Microsoft, Redmond, Washington, USA）を用いて非侵襲的に與下時の口と喉頭の運動をモ二 タリングするシステムを開発し ${ }^{12)}$ ，ささらに頭蓋内脳波と 同時に計測できる環境を構築した（図 1 ）。嬿下時の脳活 動を解析した結果，中心下領域を含むシルビウス裂に沿っ た脳皮質領域にHigh $\gamma$ 活動が出現することを明らかにし た ${ }^{13)}$ 。 また頭蓋内電極から得られた嚥下関連脳信号をイ メージデー夕に変換し，AlexNetを用いて深層転移学習 （Deep transfer learning）を行い，74\%の精度で與藏下関連 脳信号を識別できることを示した ${ }^{14)}$. 本稿は「A Swallowing Decoder Base on Deep Transfer Learning: AlexNet Classification of the Intracranial Electrocorticogram, Hashimoto, H., et al, IJNS, 2020$\rfloor^{14)}$ を元に執筆されてい る.

\section{方法}

難治部分てんかんのてんかん焦点切除術の術前精査のた め $4 \times 5$ の 20 極シート型頭蓋内電極（ユニークメディカ ル, 東京, 日本) を中心溝外側領域（口腔顔面領域に相当） に留置したてんかん患者 8 名（表 1 ) の協力を得て嚥下時 頭蓋内脳波計測を行った。頭蓋内電極は 128 チャンネルデ ジタル脳波計 (EEG 2000; 日本光電, 東京, 日本) を用い
表 1 被験者一覧

\begin{tabular}{cccc}
\hline \hline Participant & Age/sex & Diagnosis & $\begin{array}{c}\text { Number of } \\
\text { Orofacial electrodes } \\
\text { (Total Electrodes) }\end{array}$ \\
\hline P1 & $36 \mathrm{y} / \mathrm{F}$ & L TLE & $18(68)$ \\
P2 & $30 \mathrm{y} / \mathrm{F}$ & L TLE & $20(84)$ \\
P3 & $18 \mathrm{y} / \mathrm{F}$ & R TLE & $18(55)$ \\
P4 & $24 \mathrm{y} / \mathrm{M}$ & L TLE & $15(69)$ \\
P5 & $51 \mathrm{y} / \mathrm{M}$ & L TLE & $20(72)$ \\
P6 & $28 \mathrm{y} / \mathrm{M}$ & R TLE & $20(96)$ \\
P7 & $20 \mathrm{y} / \mathrm{M}$ & L TLE & $20(94)$ \\
P8 & $15 \mathrm{y} / \mathrm{F}$ & L TLE & $20(68)$ \\
\hline
\end{tabular}

M, Male; F, Female; R, Right; L, Left; TLE, Temporal lobe epilepsy

て記録した (sampling rate : $1000 \mathrm{~Hz}$ ).

課題として水の自由嚥下を行った。シリンジを用いて被 験者の口腔内に水約 $2 \mathrm{ml}$ を注入し, 外部からの合図なく自 らのタイミングで自由嚥下を指示した。約 20 分の計測時 間の間で被験者が可能な限り水嚥下課題を継続した。1 回 の與燕下動作が完了したことを確認した後，口腔内に水を注 入した

嚥下開始時間の非侵襲的な特定のため被験者の頸部には インピーダンス変化を計測する電気声門図 (EGG) (Laryngograph Ltd, ロンドン, UK) の電極と咽喉マイク (SH-12iK, 南豆無線, 静岡, 日本) を設置し, 我々が独自 開発したKinect v2 を用いた非侵襲的嚥下モニタリングシ ステム ${ }^{12)}$ も同時計測した (図 1). 電気刺激装置 (NS-101, ユニークメディカル，東京，日本）を用いて同期信号をい

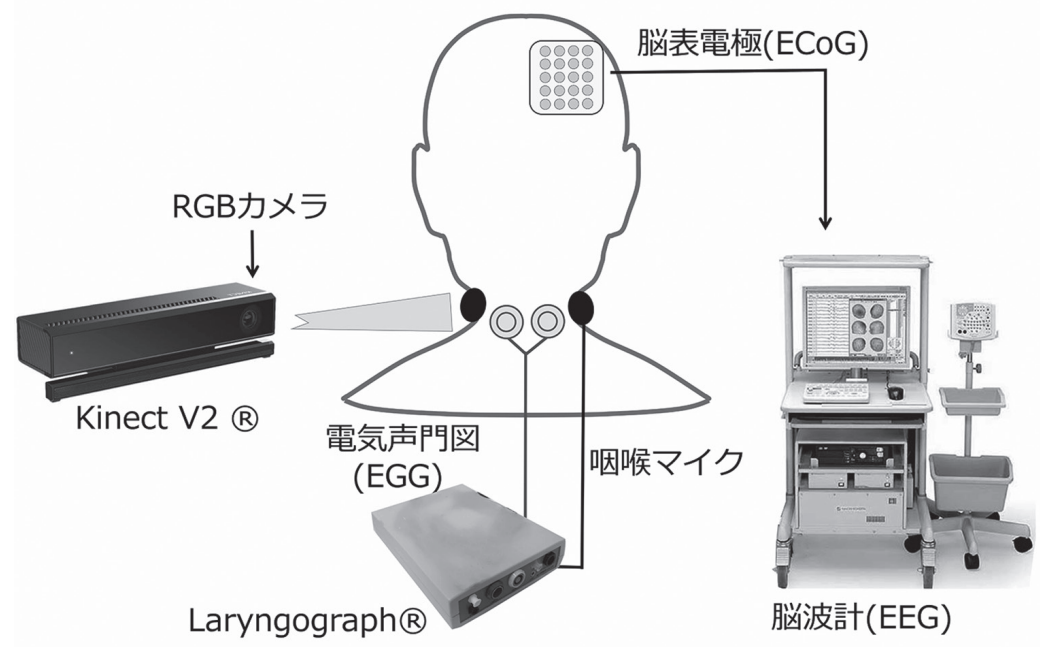

図 1 マルチモーダル嚥下計測。嚥下運動を電気声門図, 咽喉マイク, Kinect v2 を用 いた非侵襲的與下モニタリングシステムを用いて計測しつつ, 同時に脳表電極か ら頭蓋内脳波を計測した。 
(a)

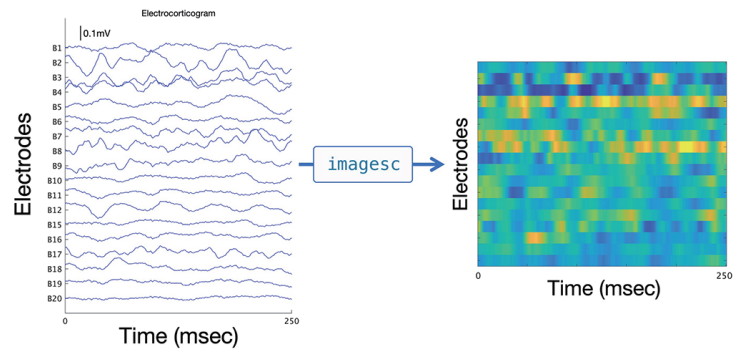

(b)

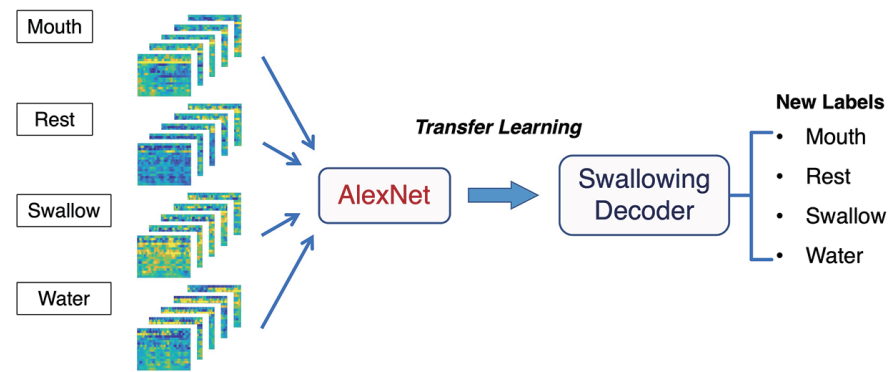

図 2 AlexNetを用いた転移学習.（a） $250 \mathrm{msec}$ 相当の頭蓋内電極から得られた信号をイメージデー夕に変換した。横軸は時間に，縦 軸は各電極に相当する。（b）開口時 (Mouth), 安静時 (Rest), 嚥下時 (Swallow), 水注入時 (Water)に相当するイメージデータ セットを準備し, AlexNetを用いて転移学習を行った。

れた。

頸部のインピーダンス変化と嚥下音声を同時計測するこ とで鱟下開始時間を非侵襲的に特定することが可能であ る ${ }^{15)}$. 電気声門図変化と鱟下音声が同時に計測された場 合を䀰下と判断し，実際に嚥下が行われているかどうかを 非侵襲的讌下モニタリングシステムのRGBカメラのビデ オ画像で確認した. RGBカメラにより被験者が開口した時 間，水が注入された時間も特定することができた。

術前の頭部MRI画像から FreeSurfer（https://surfer. nmr.mgh.harvard.edu）を用いて脳の 3 次元データを作成 L, Brainstorm (http://neuroimage.usc.edu/brainstorm/) 上で術後の頭部 CT 画像と重ね合わせた. Brainstormを用 いて術後頭部 CT 画像から頭蓋内電極の標準脳座標を取得 し 3 次元脳データ上に表示させた.

脳波は 20 極シート型電極から記録された波形の平均值 をリファレンスとして導出した，脳波データを開口時，口 腔への水注入時, 嬿下開始時でそれぞれ揃え, 1 - $200 \mathrm{~Hz}$ の時間周波数解析を打こなった(EEGLAB version 13.5.4b, http://sccn.ucsd.edu/eeglab/).

頭蓋内脳波から嚥下意図を解読するためにAlexNetを用 いた転移学習を行った. AlexNetとは 2012 年の ImageNet Large Scale Visual Recognition Challenge (ILSVRC)にて 最も高い判別精度を示した畳み込みニューラルネットワー クである ${ }^{16)}$. AlexNetは一般公開されており，すでに大量 のイメージデータにより学習済みである。転移学習とは, 学習済みのニューラルネットワークを新しいデータセット に再利用 (転移) することである。転移学習により，少な いデー夕に対しても深層学習の手法を応用でき, 一から学 習させた場合, 多量のデータと時間を必要とする深層学習 に执いてデータと時間の節約が可能である ${ }^{17)}$.

転移学習の学習用イメージを作成するため, 安静時, 開 口時, 水注入時, 與下時の脳波 $250 \mathrm{msec}$ 分をMATLAB R2019b（MathWorks, Natick, MA, USA）にてイメージ デー夕に変換した（図 $2 \mathrm{a}$ )。縦軸は電極，横軸は時間に相 当する. 安静時, 開口時, 水注入時, 與下時に相当する 4
種類のイメージデータ群を作成し，被験者一人当たり平均 670 枚の学習イメージを用意した。画像の元となる脳波 デー夕は生波形，もしくはバンドパスフィルター処理とヒ ルベルト変換との組み合わせで各周波数帯域のパワー波形 を算出 ${ }^{18)}$ し使用した。周波数帯域は $\delta$ 帯域 $(1 \sim 4 \mathrm{~Hz})$, $\theta$ 帯域 $(4 \sim 8 \mathrm{~Hz}), \quad \alpha$ 帯域 $(8 \sim 13 \mathrm{~Hz}), \beta$ 帯域 $(13 \sim 30$ $\mathrm{Hz})$, low $\gamma$ 帯域 $(30 \sim 50 \mathrm{~Hz})$, High $\gamma$ 帯域 $(75 \sim 150$ $\mathrm{Hz}$ である.

オープンソースであるAlexNetを用いてMATLAB上で 転移学習を行なった. AlexNetの最後の全結合層は安静, 開口, 注水, 燕下の 4 つの出力層に, 最終層は分類出力層 に置き換えた。作成した学習用イメージは $975 \times 1167$ $\times 3$ ピクセルであったので, $227 \times 227 \times 3$ ピクセルに 変換し, AlexNetに入力し再学習させた (図 $2 b$ ). モデル の性能を評価するために 10-fold交差検定を行なった.

統計解析のためウィルコクソンの符号順位検定を行っ た。多重検定補正はボンフェロー二法を用い, 補正 $\mathrm{p}$ 值が 0.05 未満を統計的に有意と規定した。

本研究は大阪大学医学部附属病院倫理委員会の承認を得 ている(番号 08061，16469).

\section{結果}

代表症例の頭蓋内電極位置と時間周波数解析の結果を図 3 にしめす。中心溝とシルビウス裂に挟まれ狭い脳回であ る中心下領域（subcentral area）に留置した 9 番電極（Ch 9）(図 3a）において, 與下の約 1 秒前から High $\gamma$ 帯域の 活動が観察された（図 $3 b)$ 。一方, 一次感覚野に留置した Ch 3 や, 一次運動野に留置されたCh 7 では嬹下時に同様 の活動は観察されなかった。また口腔に水が注入された際 にはCh 3 において強いHigh $\gamma$ 活動が観察され, 開口時に はCh 7 において $\beta$ 带域の抑制が観察された。このように, 嚥下に関連し異なる時間に異なる脳部位の活動が観察さ れ，特にHigh $\gamma$ 活動が著名であることから, High $\gamma$ 帯域 は與下意図解読のための良い特徵量になるのではないかと 予想された。 
(a)

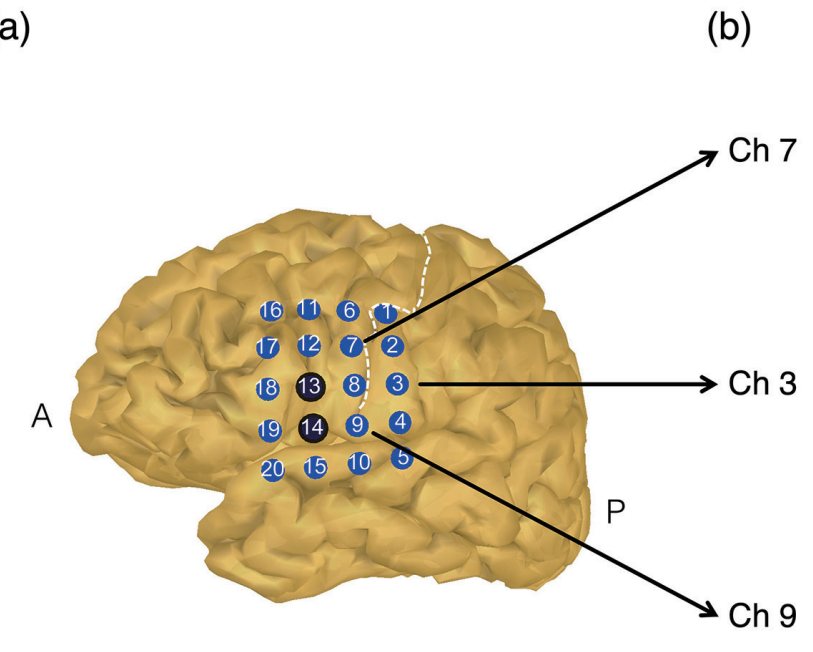

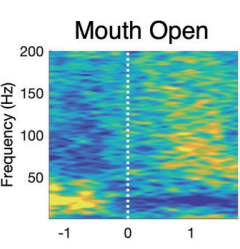
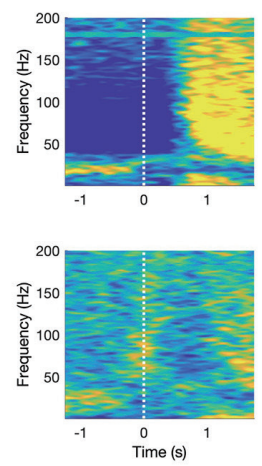

Water Injection
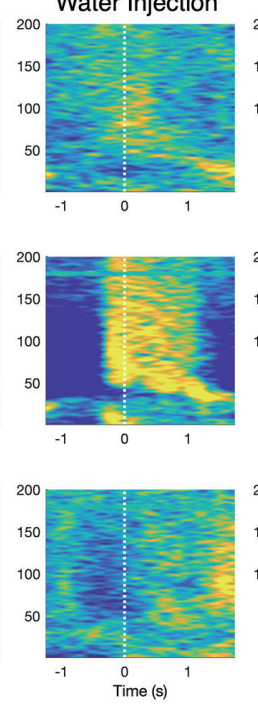

Swallow
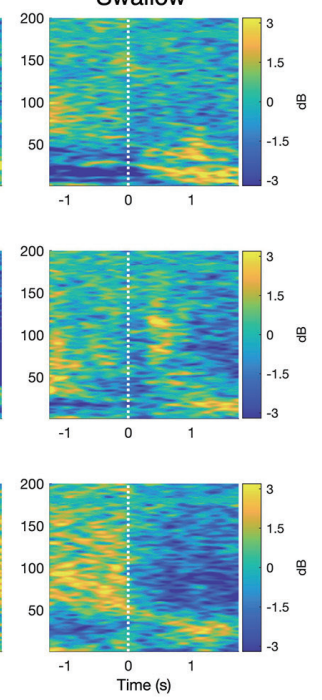

図 3 代表症例における大脳皮質・口腔顔面領域での開口, 水注入, 嚥下関連脳律動変化.（a）口腔顔面領域に敷設された 20 極シー 卜型頭蓋内電極マップ. 13，14で示された電極はノイズのため解析から除外した電極. 白色破線は中心溝を示す。A: anterior, P: posterior. (b) Ch 7 は一次運動野, Ch 3 は一次感覚野, Ch 9 は中心下領域に敷設されている. 開口時にはCh 7 にて $\beta$ 带域の抑制が, 水の注入時にはCh 3 で著名なHigh $\gamma$ 活動が, 嚥下時には嚥下の約 1 秒前からCh 9 においてHigh $\gamma$ 活 動が観察された.

(a)

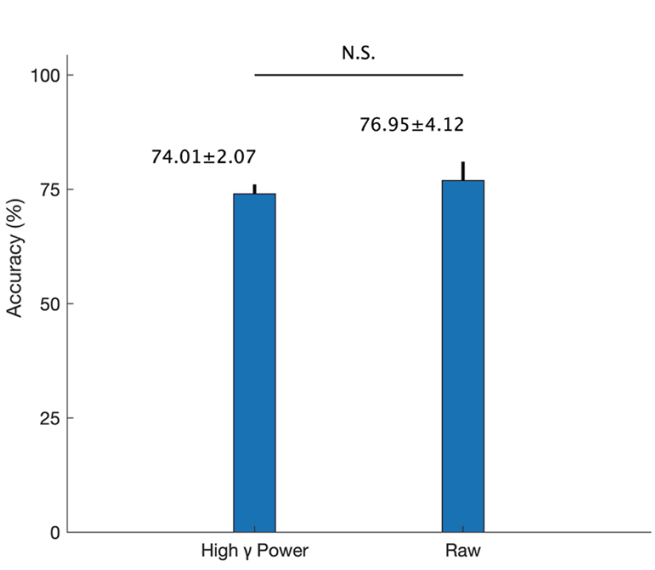

(b)

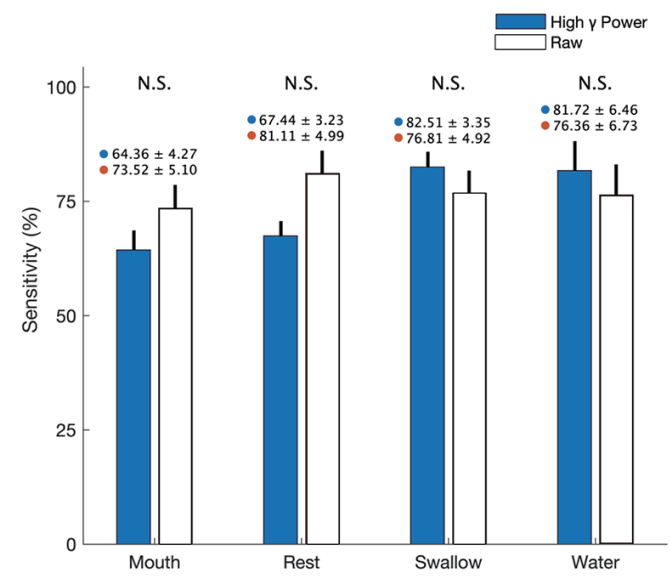

図 4 学習データに頭蓋内脳波の生波形を使用した場合と, High $\gamma$ パワーを使用した場合での転移 学習のパフォーマンスの比較. (a) High $\gamma$ パワーと生波形の間に解読精度の統計学的違いは なかった（ウィルコクソンの符号順位検定）。（b）各ラベルでの感度を比較したが, 統計学的 有意差を認めなかった (ウィルコクソンの符号順位検定, ボンフェローニ法併用).

次に転移学習の結果を図 4 に示す，脳波の生波形から作 成したイメージを学習デー夕に使用した場合, 精度は $76.95 \pm 4.12$ (平均 \pm 標準誤差 $(\mathrm{SE})$ ) \%であった。一 方, High $\gamma$ パワーを用いて学習用イメージを作成した場 合の精度は $74.01 \pm 2.07$ (平均 $\pm \mathrm{SE}$ ) \%であり，両者を 比較したが有意差を認めなかった（図 $4 \mathrm{a}$ )。各ラベルの感 度を図 $4 \mathrm{~b}$ に示す。開口, 安静, 嚥下, 注水の各ラベルに
おいて, 生波形から得られた結果とHigh $\gamma$ パワーから得 られた結果の間で有意差を認めなかった。たた，䶷下と注 水に扔いてはHigh $\gamma$ パワーから得られた感度の方が高く なる傾向が見られた。

最後に各周波数帯域別での解読精度の結果を図 5 に示 す. High $\gamma$ パワーを用いた場合に最も高い解読精度を認 め $(74.01 \pm 2.07 \%)$, 他の周波数帯域と比較したところ 


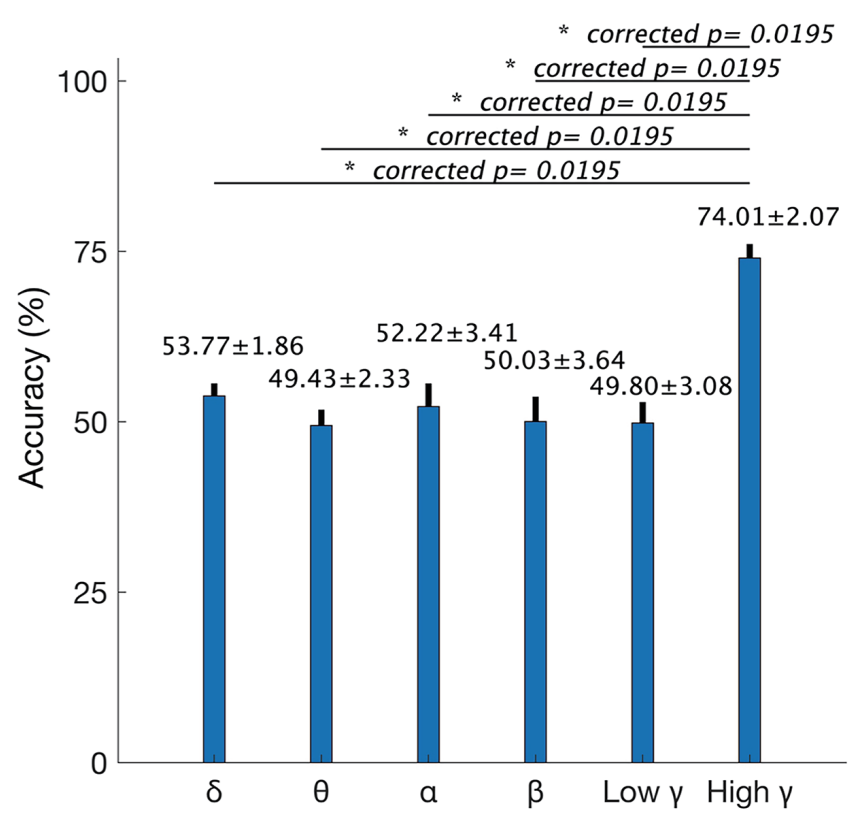

図 5 各周波数帯域パワーにおける解読精度の比較. High $\gamma$ パワーを使用した場合, 最も高い解読精度を示し，他の 周波数帯域より統計学的に有意に高かった（ウィルコク ソンの符号順位検定，ボンフェロー二法併用，補正 $\mathrm{p}$ 值 $<0.05)$.

統計学的に有意に高いことが示された（ウイルコクソンの 符号順位検定, 補正 $\mathrm{p}$ 值 $=0.0195$ ， ボンフェローニ法を 併用)。以上より，嚥下に関連しHigh $\gamma$ 活動が大脳皮質に 誘発され，同活動を用いることで高い解読精度を実現でき ることが示された。

\section{考察}

我々の一連の研究結果を紹介した。まず頭蓋内脳波と同 時計測可能な非侵襲的嚥下モニタリングシステムを開発し 報告した ${ }^{12)}$ 。次に與燕下に関連し異なる時間に異なる領域 において High $\gamma$ 活動が出現することを示し ${ }^{13)}$, High $\gamma$ 活 動を転移学習と組み合わせて使用すれば嚥下意図の解読を 高い精度で実現できることを示した ${ }^{14)}$ 。本稿では主に曣 下意図の解読に焦点を当て紹介した。

過去の $\mathrm{fMRI}^{1}{ }^{19)}$ を用いた研究やPET ${ }^{2)}$ を用いた研究か ら, 中心下領域 (BA 43) や前頭弁蓋部 (BA 44), また体 性感覚運動野の外側領域 (BA 1, 2, 3,4) が鱟下の準備や 実行に重要であることがわかっていた，本稿でも High $\gamma$ 帯域の活動が與㸃下に関連し中心下領域に出現することを示 した。また水が口腔内に注入された際には，中心後回に留 置した電極においてHigh $\gamma$ 帯域の活動が著名であった. 同部位は一次感覚野の口腔顔面領域であることが文献的に 知られており ${ }^{20)}$, このHigh $\gamma$ 帯域の活動は口腔内からの 感覚入力により引き起こされたと推察される。

中心下領域は舌の運動 ${ }^{5,21)}$ や閉口運動 ${ }^{22)}$ によっても活 動することが報告されている。一方，中心下領域は與䔧下運
動時にも口腔内の感覚入力時にも活動し, 両者によって活 動する脳領域に違いはない, とする fMRIの研究 ${ }^{23)}$ がある が, これはfMRIの時間分解能が低い ${ }^{24)}$ ため嚥下により特 異的に活動する脳領域と, 口腔内への感覚入力に関連した 脳活動領域を弁別できていない可能性がある。中心領域 の機能は未だ明らかでなく ${ }^{25)}$ ，一説によると島回と密に 連携するとともに一次感覚野からの神経線維入力を受け感 覚情報を統合する領域であるとされる ${ }^{26,27)}$ 。感覚入力が 正常嚥下の開始と調整に重要であり ${ }^{28)}$, 中心下領域の障

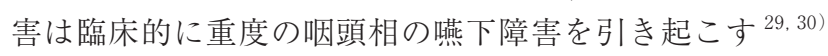
ことからも中心下領域が與下実行に重要な役割を担う皮質 領域の一部であると考える。

本稿では頭蓋内電極から得られた信号をイメージデー夕 に変換し，それらを学習用データとしてAlexNetを用いて 転移学習を行なった。転移学習が超音波 ${ }^{31)}, \mathrm{MRI}^{32)}$, $\mathrm{CT}^{17)}$ などの医用画像の識別に有用であることは既に報告 されている。これらの医用画像は画像的に意味を持ち, 目 視で識別することが可能である. AlexNetも意味のあるイ メージデー夕を用いて事前に学習済みであるが，本稿では 頭蓋内電極から得られた画像的に意味のないイメージデー 夕を用いて転移学習を行なったとしても高い解読精度を実 現できることを示した，また事前に口腔顔面領域の電極に おいて與下時に活動が起きることがわかっていたため, 口 腔顔面領域に敷設した頭蓋内電極を選択的に用いたことも 高い解読精度達成に寄与したと推察される。

過去の研究から High $\gamma$ 帯域の活動を用いることでより 高い解読精度が得られる ${ }^{6.7)}$ ことが報告されており，この 知見は本稿の結果と一致する. High $\gamma$ パワーから得られ たイメージを使用し転移学習を実行した場合, 低周波帯域 のパワーを使用した場合に比べ統計学的に有意に高い解読 精度を達成することができた。この結果は, High $\gamma$ 活動 が他の周波数帯域に比べより脳機能局在を反映してい る ${ }^{33)}$ ことと関係していると思われる.

転移学習の研究を計画している段階で, 我々は頭蓋内電 極からの生波形を使用するよりもHigh $\gamma$ パワーを学習 データに用いる方が，高い解読精度を実現できるのではな いか，と予想していた。しかし実際の結果はそうではな かった，頭蓋内脳波の生波形を使用しても，その解読精度 はHigh $\gamma$ パワーを使用した場合に匹敵していた，本研究 では転移学習の学習データとしてイメージデータを使用し ているが, 生波形から得られイメージにはHigh $\gamma$ 帯域の 情報が含まれているのではないかと推察された。ただし， 燕下や水注入の識別感度においては, High $\gamma$ パワーの方 が生波形に比べ感度が高い傾向が見られた。これは嚥下時 や水の注入時に著名なHigh $\gamma$ 活動が引き起こされること に関係しているものと考えられた。

現在，ニューロモデュレーションの見地から経頭蓋反復 磁気刺激 (rTMS) ${ }^{34)}$ や経頭蓋直流刺激 (tDCS $)^{35}$, 36) が新 たな嚥下障害のアプローチとして研究されている。rTMS 
の先行研究によると健側運動皮質の咽頭領域に対する高頻

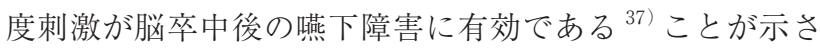
れている，本研究により嚥下時に活動することが明らかに なった中心下領域はニューロモデュレーションの新たな ターゲットとしての潜在的可能性を有するのではないかと 考える. また本稿で示した嚥下時脳波の解読はオフライン での実証であり，鱟下補助BMIの実現にはオンラインで の解読が必要である。さらに本研究結果は頭蓋内電極とい う侵襲的な方法で得られたデー夕を元にしており，より一 般化させるには非侵襲的な計測法でも実現できるかさらな る実証が必要である。

\section{謝辞}

本研究の一部は科学研究費助成事業の基盤研究 (A)「頭 蓋内脳波を用いた嚥下の脳機能解明とブレインマシンイン ターフェイス」(18H04166), 基盤研究 (B)「ブレインマ シンインターフェイスを用いた嚥下機能の再建」(No. 26282165), 若手研究「ヒ卜嚥下関連脳律動解析と嬹下時 脳信号解読」（18K18366）の支援によって行われた.

本論文は, 第 32 回日本喉頭科学会総会・学術講演会 （2020.9.4, 仙台）にて領域講習とした内容に加筆修正し作 成された。

本論文に関連し，企業・組織または団体との利益相反 (COI) はない.

\section{文献}

1) Hamdy S, Mikulis DJ, Crawley A et al : Cortical activation during human volitional swallowing : an eventrelated fMRI study. Am J Physiol 277 : 219-225, 1999.

2) Hamdy S, Rothwell JC, Brooks DJ et al : Identification of the cerebral loci processing human swallowing with H2 (15) O PET activation. J Neurophysiol 81 : 1917 1926, 1999

3) Dziewas R, Soros P, Ishii R et al : Neuroimaging evidence for cortical involvement in the preparation and in the act of swallowing. NeuroImage $20: 135-144$, 2003.

4) Yang H, Guan C, Chua KS et al : Detection of motor imagery of swallow EEG signals based on the dualtree complex wavelet transform and adaptive model selection. J Neural Eng 11:035016, 2014.

5) Satow T, Ikeda A, Yamamoto J et al : Role of primary sensorimotor cortex and supplementary motor area in volitional swallowing : a movement-related cortical potential study. Am J Physiol Gastrointest Liver Physiol 287: G459-470, 2004.

6) Yanagisawa $T$, Hirata M, Saitoh $Y$ et al : Real-time control of a prosthetic hand using human electrocorti- cography signals. Journal of Neurosurgery $114: 1715$ 1722, 2011.

7) Yanagisawa T, Hirata M, Saitoh $Y$ et al : Electrocorticographic control of a prosthetic arm in paralyzed patients. Annals of Neurology $71: 353-361,2012$.

8) Crone NE, Miglioretti DL, Gordon B et al : Functional mapping of human sensorimotor cortex with electrocorticographic spectral analysis. II. Event-related synchronization in the gamma band. Brain 121 : 2301 2315, 1998.

9) Jones MS, Barth DS : Sensory-evoked high-frequency (gamma-band) oscillating potentials in somatosensory cortex of the unanesthetized rat. Brain Res 768 : 167 176, 1997.

10) Hashimoto H, Hasegawa Y, Araki T et al : Noninvasive detection of language-related prefrontal high gamma band activity with beamforming MEG. Sci Rep $7: 14262,2017$.

11) Pipa G, Stadtler ES, Rodriguez EF et al : Performanceand stimulus-dependent oscillations in monkey prefrontal cortex during short-term memory. Front Integr Neurosci $3: 25,2009$.

12) Hashimoto H, Hirata M, Takahashi $K$ et al : Noninvasive quantification of human swallowing using a simple motion tracking system. Sci Rep-Uk 8 : 5095, 2018.

13) Hashimoto H, Takahashi K, Kameda S et al : Motor and sensory cortical processing of neural oscillatory activities revealed by human swallowing using intracranial electrodes. bioRxiv : 2020.

14) Hashimoto H, Kameda S, Maezawa $\mathrm{H}$ et al : A swallowing decoder based on deep transfer learning: AlexNet classification of the intracranial electrocorticogram. International Journal of Neural Systems, 2020.

15) Firmin H, Reilly S, Fourcin A : Non-invasive monitoring of reflexive swallowing. Speech Hearing and Language $10:$ 171-184, 1997.

16) Krizhevsky A, Sutskever I, Hinton G : ImageNet classification with deep convolutional neural networks. In NIPS. 1097-1105, 2012.

17) Dawud AM, Yurtkan K, Oztoprak H : Application of deep learning in neuroradiology : Brain haemorrhage classification using transfer learning. Computational Intelligence and Neuroscience 2019, 2019.

18) Cohen MX. : Assessing transient cross-frequency coupling in EEG data. J Neurosci Methods 168 : 494-499, 2008.

19) Martin RE, Goodyear BG, Gati JS et al : Cerebral cortical representation of automatic and volitional swallow- 
ing in humans. J Neurophysiol 85 : 938-950, 2001.

20) Salmelin R, Hamalainen M, Kajola M et al : Functional segregation of movement-related rhythmic activity in the human brain. NeuroImage $2: 237-243,1995$.

21) Martin RE, MacIntosh BJ, Smith RC et al : Cerebral areas processing swallowing and tongue movement are overlapping but distinct : a functional magnetic resonance imaging study. J Neurophysiol $92: 2428$ 2443, 2004.

22) Mihai PG, von Bohlen Und Halbach O, Lotze M : Differentiation of cerebral representation of occlusion and swallowing with fMRI. Am J Physiol Gastrointest Liver Physiol 304 : 847-854, 2013.

23) Lowell SY, Poletto CJ, Knorr-Chung BR et al : Sensory stimulation activates both motor and sensory components of the swallowing system. NeuroImage $42: 285$ 295, 2008.

24) Aine CJ : A conceptual overview and critique of functional neuroimaging techniques in humans : I. MRI/ FMRI and PET. Crit Rev Neurobiol 9 : 229-309, 1995.

25) Hirsch J, Zhang X, Noah JA et al : Frontal temporal and parietal systems synchronize within and across brains during live eye-to-eye contact. NeuroImage 157 : 314-330, 2017.

26) Toogood JA, Smith RC, Stevens TK et al : Swallowing preparation and execution: Insights from a delayedresponse functional magnetic resonance imaging (fMRI) study. Dysphagia 32 : 526-541, 2017.

27) Saper CB : Hypothalamic connections with the cerebral cortex. Prog Brain Res 126 : 39-48, 2000.

28) Gow D, Hobson AR, Furlong P et al : Characterising the central mechanisms of sensory modulation in human swallowing motor cortex. Clin Neurophysiol 115 : 2382-2390, 2004.

29) Weller M : Anterior opercular cortex lesions cause dissociated lower cranial nerve palsies and anarthria but no aphasia : Foix-Chavany-Marie syndrome and "automatic voluntary dissociation" revisited. J Neurol
240 : 199-208, 1993.

30) Alberts MJ, Horner J, Gray L et al : Aspiration after stroke : lesion analysis by brain MRI. Dysphagia 7 : 170-173, 1992.

31) Cheng PM, Malhi HS : Transfer learning with covolutional neural networks for classification of abdominal ultrasound images. Journal of Digital Imaging 30 : 234243, 2017.

32) Lu S, Lu Z, Zhang Y-D : Pathological brain detection based on AlexNet and transfer learning. Journal of Computational Science $30:$ 41-47, 2019.

33) Crone NE, Miglioretti DL, Gordon B et al : Functional mapping of human sensorimotor cortex with electrocorticographic spectral analysis. I. Alpha and beta event-related desynchronization. Brain 121 : 2271 2299, 1998.

34) Verin E, Leroi AM : Poststroke dysphagia rehabilitation by repetitive transcranial magnetic stimulation : a noncontrolled pilot study. Dysphagia 24: 204 - 210, 2009 .

35) Vasant DH, Mistry S, Michou E et al : Transcranial direct current stimulation reverses neurophysiological and behavioural effects of focal inhibition of human pharyngeal motor cortex on swallowing. J Physiol 592 :695-709, 2014.

36) Suntrup S, Teismann I, Wollbrink A et al : Magnetoencephalographic evidence for the modulation of cortical swallowing processing by transcranial direct current stimulation. NeuroImage $83:$ 346-354, 2013.

37) Park JW, Oh JC, Lee JW et al : The effect of $5 \mathrm{~Hz}$ high-frequency rTMS over contralesional pharyngeal motor cortex in post-stroke oropharyngeal dysphagia : a randomized controlled study. Neurogastroenterology \& Motility $25: 324,2013$.

別刷請求先 $\bar{\top}$ 540-0008 大阪府大阪市中央区大手前 1-5-34 大手前病院脳神経外科

橋本洋章 